\title{
Entrepreneurial orientation and export performance: the mediating effect of organisational resources and dynamic capabilities
}

\author{
Albertina Paula Monteiro \\ School of Accounting and Administration, Polytechnic of Porto, \\ Rua Jaime Lopes Amorim, $\mathrm{s} / \mathrm{n}$, \\ 4465-004 S. Mamede de Infesta, Portugal \\ Email: amonteiro@iscap.ipp.pt
}

\section{Ana Maria Soares}

School of Economics and Management, University of Minho

Campus de Gualtar 4710-057 Braga, Portugal

Email: amsoares@eeg.uminho.pt

\section{Orlando Lima Rua}

School of Accounting and Administration, Polytechnic of Porto, Rua Jaime Lopes Amorim, s/n, 4465-004 S. Mamede de Infesta, Portugal Email: orua@iscap.ipp.pt

\begin{abstract}
This study analyses the relationships among entrepreneurial orientation, organisational resources, dynamic capabilities, and export performance. Specifically, we propose that entrepreneurial orientation enhances the attraction of financial, informational and relational resources thus affecting export performance through dynamic capabilities. This model is empirically tested with data from 265 managers of exporting companies in Portugal. Results validate ten out of eleven direct relationships of the model and confirm the mediating effect of organisational resources and dynamic capabilities on export performance. Entrepreneurial orientation contributes to the attraction of relational and informational resources, relational resources boost the development of informational and financial resources, and these three types of organisational resources directly affect the development of dynamic capabilities and export performance. In what concerns the managerial implications, managers, public policy makers, and researchers aiming to contribute to firms' competitiveness and performance must clearly understand how resources affect the development of differentiated dynamic capabilities.
\end{abstract}

Keywords: export performance; resource-based view; dynamic capabilities approach; DCA; entrepreneurial orientation; financial resources; relational resources; informational resources; structural equation modelling. 
Reference to this paper should be made as follows: Monteiro, A.P., Soares, A.M. and Rua, O.L. (2017) 'Entrepreneurial orientation and export performance: the mediating effect of organisational resources and dynamic capabilities', J. International Business and Entrepreneurship Development, Vol. 10, No. 1, pp.3-20.

Biographical notes: Albertina Paula Monteiro is a Lecturer of Accounting and Management in the School of Accounting and Administration of the Polytechnic of Porto and ISAG - European Business School. Her research focuses on entrepreneurship, export performance and service quality. She presented her research in several international conferences and has published in the Euromed Journal of Business.

Ana Maria Soares is an Assistant Professor of Marketing and Strategic Management at the School of Economics and Management, University of Minho, Portugal. She conducts research in international marketing and strategy and international consumer behaviour. Her papers have been published in Journal of Business Research, International Journal of Consumer Studies, International Journal of Cross-Cultural Management and Journal of Research in Interactive Marketing among others.

Orlando Lima Rua is a Lecturer of Management in the School of Accounting and Administration of the Polytechnic of Porto. He has presented his work in several national and international scientific conferences and journals.

This paper is a revised and expanded version of a paper entitled 'Linking entrepreneurial orientation to export performance: the role of intangible resources and dynamic capabilities' presented at the 6th Annual EuroMed Conference, Estoril, Portugal, 23-24 September 2013.

\section{Introduction}

As a consequence of ever-increasing globalisation, companies are faced with foreign competitors in their domestic markets and are led to explore and develop their activities in international markets (Etemad, 2005). Internationalisation is, in this context, a strategic option for the expansion and growth of entrepreneurial companies. International markets are particularly competitive, and export managers need to compete to the best of their ability (Morgan et al., 2006). In fact, there is widespread recognition in the literature that success in internal markets does not guarantee success in external markets. Hence, defining adequate strategies for export markets is crucial (Cavusgil and Zou, 1994). The resource-based view (RBV) emphasises that the ownership of strategic resources enables companies to gain competitive advantage. Recent studies have shifted the focus on tangible resources to intangible resources, which are deemed more important from a strategic viewpoint and more relevant for business performance and success (Bakar and Ahmad, 2010; Morgan et al., 2006). Moreover, recent research has focused on the dynamic capabilities as a source of sustainable competitive advantage (López, 2005; Teece, 2007; Teece et al., 1997; Wu, 2010), endowing the theory of resources and capabilities with a more dynamic approach. 
Drawing on the RBV and the dynamic capabilities approach (DCA), this study aims to evaluate the interaction between entrepreneurial orientation and export performance, by examining the mediating effect of intangible resources (available for the international market) and dynamic capabilities. Companies need to understand the processes that lead to superior performance in terms of exports. Although export performance has been addressed in a vast number of studies, it remains one of the least understood and most contentious areas of international marketing (Katsikeas et al., 2000). Understanding how resources affect the development of differentiated dynamic capabilities is relevant both for managers, public policy makers, and researchers aiming to contribute to firms' competitiveness and performance.

This paper is organised as follows: In the next section, we present the theoretical framework of the study and discuss the role of resources and capabilities and export performance. The third section presents the research model and hypothesis. Section 4 describes the method used in this research, while Section 5 presents and discusses our major findings. Finally, in Section 6, we present the study conclusions, limitations, and suggestions for further research.

\section{Theoretical framework}

\subsection{Resources and capabilities}

The role of resources and capabilities in achieving and in maintaining competitive advantages is one of the main topics in international entrepreneurship (Young et al., 2003). This approach is a cornerstone of RBV which became one of the most established theories of strategic management (Newbert, 2007). The RBV draws on the premise that strategic resources and capabilities enable companies to gain competitive advantage (Peteraf, 1993; Barney, 1991; Wernerfelt, 1984).

A company's competitive advantage is defined by Barney $(1991, \mathrm{p} .102)$ as a "value creating strategy not simultaneously being implemented by any current or potential competitors". Furthermore, the RBV states that a competitive advantage cannot exist for identical companies, because these companies "all implement the same strategies, [and thus] they all will improve their efficiency and effectiveness in the same way, and to the same extent" [Barney, (1991), p.104]. In broad terms, competitive advantage means that a company can perform better than its competitors by using the same assets and/or competencies (Lee and Hsien, 2010).

Resources are assets that the company owns, controls, or has access to on a semi-permanent basis (Wernerfelt, 1984; Helfat and Peteraf, 2003), which can be tangible or intangible. The literature has recognised different types of resources, including technological, financial, human, physical, and organisational assets (Bakar and Ahmad, 2010; Loane and Bell, 2006). Wernerfelt (1984) argues that the concept of resources is limited to the attributes that increase a company's efficiency and effectiveness. Furthermore, resources should have some ability to generate profits or avoid losses (Miller and Shamsie, 1996). In this sense, the resources refer not only to companies' assets but also to their capabilities (Henderson and Cockburn, 1994).

Capability refers to the firm's ability to perform a coordinated set of tasks, using organisational resources, to achieve a specific result (Helfat and Peteraf, 2003). According to Amit and Schoemaker (1993), capability refers to the firm's capacity to 
mobilise resources, generally in combination, using organisational processes, for a desired end effect.

The RBV is based on the assumption that a firm's resources/capabilities must be rare, valuable, irreplaceable, and inimitable (Barney, 1991). Furthermore, the RBV holds that differences in performance are an outcome of the heterogeneity in resources controlled by companies, which affect the company's ability to develop and implement competitive strategies (Barney, 1991; Peteraf, 1993). As such, access to heterogeneous resources and capabilities directly impacts company performance (Makadok, 2001; Teece et al., 1997).

In what concerns international settings, Dhanaraj and Beamish (2003) examined three sets of resources and capabilities that influence and/or reinforce corporate strategy in external markets: entrepreneurial orientation, organisational resources, and technological intensity. Their study confirmed that these strategic resources and capabilities have a positive impact on export activities and performance.

\subsection{Entrepreneurial orientation}

Entrepreneurial orientation is the focal construct of this study. We build in the perspective that entrepreneurial orientation is an organisational capability which should be understood in the context of resources and capabilities relevant for international companies' activities.

Entrepreneurial orientation has been the subject of much scholarly attention because of its impact on firms' product-market innovation and proactive strategies. Miller (1983) states that organisations with entrepreneurial orientation accept the risks associated with the innovation of products and/or markets and act proactively before their competition does. Lumpkin and Dess (1996, p.136) define entrepreneurial orientation as 'the processes, practices, and decision-making activities that lead to new entry'.

Miller (1983) proposes that entrepreneurial orientation comprises three fundamental dimensions: innovation, risk taking, and proactiveness. Lumpkin and Dess (1996) put forth two additional dimensions to characterise the entrepreneurial process - namely, competitive aggressiveness and autonomy. According to these authors, the main dimensions characterising an entrepreneurial orientation include a tendency to act autonomously, a willingness to innovate and take risks, and a tendency to be aggressive toward competitors and proactive in terms of market opportunities. However, a literature review indicates that the most commonly used dimensions in research are innovativeness, proactiveness, and risk taking (Kropp et al., 2008). Miller (1983) contends that only companies that have high levels in all three dimensions of entrepreneurial orientation (innovativeness, risk taking, and proactiveness) can be entrepreneurial.

\subsection{Financial resources}

Financial resources refer to access to cash and capital and are essential in enabling exports (Morgan et al., 2006). Some small companies are able to gradually to make savings to invest in export operations (Leonidou et al., 2007). However, financial advantage can also be obtained through the development of good relationships with financial institutions, which can contribute to the company export endeavour through credit (Leonidou et al., 2007). To Morgan et al. (2006), financial resources constitute a resource for export businesses and must be evaluated according to the level and ease of access to credit. As such, financial resources have, to a great extent, an intangible nature. 


\subsection{Informational resources}

Knowledge refers to any information, belief, or ability that firms can incorporate into their activities (Anand et al., 2002). The main barrier to the internationalisation of small businesses is the lack of knowledge (Loane and Bell, 2006).

Knowledge has been classified into explicit, i.e. accessed through training and education, and tacit, acquired though experience (Nonaka, 1991). For Katsikeas and Morgan (1994) knowledge includes the acquisition and dissemination of information about customers, competitors, distribution channels, and export market. Given its tacit nature, this type of knowledge is unique and difficult to imitate (Mowery et al., 1996) and may lead to the identification of opportunities, market knowledge, building of networks, thus encouraging internationalisation. As such, knowledge is, according to Grant (1996), the most important asset of a competitive company and constitutes one of the main incentives for a company to go international (Johanson and Vahlne, 1977) organisational resources.

\subsection{Relational resources}

Relational resources consist of the networks between the company and external entities, such as customers, suppliers, competitors, and government institutions (Davis and Mentzer, 2008). These resources are based on relationships, promise sustainable competitive advantage (in that resources are distributed asymmetrically between firms), are imperfectly mobile, are difficult to imitate, and have no substitutes (Barney, 1991). Currently, the struggle for competitive advantage in a globalised economy increasingly revolves around the value of firms' networks (Davis and Mentzer, 2008). However, a firm must establish relationships not only in terms of expected performance but also to improve capabilities that enable it to develop other resources (Arndt, 1979). This is because the relationships between the company and external entities are information flow channels for resources (Tsai and Ghoshal, 1998).

\subsection{Dynamic capabilities}

Recently, research has been focusing on the role and importance of dynamic capabilities. Several authors contend that RBV does not adequately explain how companies can achieve competitive advantage in fast-moving business environments (Eisenhardt and Martin, 2000; Teece et al., 1997). In such business landscapes, technological change is fast, the nature of the markets and competition is difficult to determine, and time to market is critical (Teece et al., 1997). In versatile markets, capabilities must be dynamic, that is, the firm must have the capability of renewing competencies to continually ensure the consistency between the business environment and strategy.

Prior research has treated dynamic capabilities as a source of sustainable competitive advantage (López, 2005; Eisenhardt and Martin, 2000; Teece, 2007; Teece et al., 1997; $\mathrm{Wu}, 2010)$. Teece et al. (1997, p.515) describe the term 'dynamic' as the 'capacity to renew competences so as to achieve congruence with the changing business environment'. They further define 'dynamic capabilities' as the firm's ability to integrate, build, and reconfigure internal and external competences to quickly respond to changes in the current business environment. Given its relevance, the theoretical approaches on recent dynamic capabilities have contributed to the distinction between capabilities and 
other resources available in the firm (Makadok, 2001; Teece et al., 1997) and have provided a broader view of the theory of resources and capabilities. Dynamic capacities allow companies to achieve superior performance in the long run (Teece, 2007). According to $\mathrm{Wu}$ (2006), a dynamic capability is a mediating variable in the relationship between organisational resources and performance.

Teece (2007, p.1320) explored the nature of dynamic capabilities and posited the core relevance of developing and exercising these capabilities for business success (and failure) as "excellence in these 'orchestration' capacities undergirds an enterprise's capacity to successfully innovate and capture sufficient value to deliver superior long term financial performance". The author also argued that access to such capabilities is especially relevant for international companies' performance, given the changing nature of the markets they operate in.

However, this approach has been neglected in internationalisation studies, although the importance of dynamic capabilities has been acknowledged in the rapidly changing international business environment and the industry structures (Hung-Hsin and Lee, 2009).

\subsection{Export performance}

Companies can resort to different entry modes to internationalise their operations and create value markets (Ireland et al., 2001). In general, exporting is considered an intermediate stage in the company development which may precede higher involvement forms of internationalisation, including foreign direct investment (Schlegelmilch and Crook, 1988; Vila and Kuster, 2007).

With the steady increase of business and international competition, understanding the determinants of exports' performance, contributed to the development of several studies in this area (Sousa et al., 2008). However, the lack of a comprehensive theoretical basis for explaining export performance makes it difficult to integrate the results of different studies in a coherent body of knowledge (Morgan et al., 2004; Sousa et al., 2008). Sousa et al. (2008) conducted a literature review between 1998 and 2005 and concluded that considerable attention has been paid to the determinants of export performance, contributing to the theoretical and practical advances in this field. However, according to these authors, the literature on export performance is fragmented (consisting of many studies that characterise the adoption of a variety of analytical and methodological approaches), different (investigates many different determinants of export performance), and inconsistent (provides different reports, often contradicting the findings on the influence of various determinants of export performance, causing confusion and misunderstanding of the factors that significantly affect performance).

Morgan et al. (2004) confirm that export performance is strongly correlated with the positional advantage of the firm in the international market and that this is directly related to the availability of resources and capabilities for external markets. Similarly, Dhanaraj and Beamish (2003) concluded that resources are good predictors of export strategy (operationalised in terms of degree of involvement in foreign markets).

In the literature, two types of indicators are used to assess export performance: objective and subjective indicators (Sousa et al., 2008). Objective measures refer to indicators that rely primarily on absolute values, such as export intensity, the volume of export sales, and export market share; conversely, subjective indicators measure 
perceived or attitudinal performance, such as export success and perceived satisfaction with export sales (Sousa et al., 2008).

The diversity of indicators to measure business performance renders it difficult to compare the results of different studies; that is, it is almost impossible to determine whether conflicting results are due to determinants (independent variables) or to the use of different scales of export performance (Zou et al., 1998). Zou et al. (1998) also report that most studies are conducted in one country, and research conducted in different countries tends to use different measures of export performance.

Sousa et al. (2008) analysed measures of export performance and concluded that despite the large number of measures of export performance (approximately 50), only a few were frequently used - namely, export intensity (share of exports in total sales), growth of export sales, export profits, export market share, satisfaction with export performance in general, and perceived export success. Less frequently used measures were return on investment, quality of relationship with the distributor, customer satisfaction, and satisfaction with quality product/service compared with competitors'.

Another important aspect in the study on export performance is the unit of analysis. Katsikeas et al. (2000) and Sousa et al. (2008) found that most of the studies analysed used the company as the unit of analysis (export performance evaluated in the context of overall business activities in foreign markets). Conversely, Cavusgil and Zou (1994) argued that the unit of analysis should be the 'export venture', defined as the combination of a single product or product line exported to the main market (Lages and Montgomery, 2004), because firms can have more than one product or product line, and each may have a different impact on export performance (Sousa et al., 2008). The focus on the export venture contributes to a more accurate assessment of the factors associated with superior export performance (Piercy et al., 1998). Indeed, many managers develop a marketing strategy just for the primary market, while secondary markets have no defined strategy or are subjected to the strategy defined for the primary market (Lages and Montgomery, 2004).

Several educations contend that each of the dimensions of entrepreneurial orientation impacts positively the performance of companies, to the extent that it enhances the commitment to innovation, leading to the creation of new products and services, the search of new opportunities and markets, among others (Lumpkin and Dess, 1996; Miller, 1983; Alvarez and Busenitz, 2001; Wiklund and Shepherd, 2005). This notion is in line with the Schumpeterian view that innovative companies have an outstanding performance and can be seen as drivers of the economic development of countries (Schumpeter, 1934). Moreover, proactive companies may benefit from first mover advantages (Zahra and Covin, 1995).

\section{Research model}

Drawing on the RBV and the DCA, this study aims to examine the relationship among entrepreneurial orientation, organisational resources, and dynamic capabilities on export performance. Although literature suggests that resources and capabilities are related (Dhanaraj and Beamish, 2003; Morgan et al., 2004) and sustains that entrepreneurs have a unique cognitive ability of to recognise venture opportunities and organise resources (Alvarez and Busenitz, 2001), studies looking for the impact of resources and capabilities in international performance are scarce. 
Specifically, using the previously reviewed contributions as a basis, we focus on the role of entrepreneurial orientation in capturing organisational resources (financial, informational and relational resources) and the role of such resources in the development of dynamic capabilities. This study also aims to evaluate the impact of resources and capabilities on international business performance, assessing how and to what extent resources and capabilities influence export performance. Finally, the study assesses the mediating effect of organisational resources and dynamic capabilities between entrepreneurial orientation and export performance. Figure 1 presents the proposed research model and hypothesis.

Figure 1 Research mode

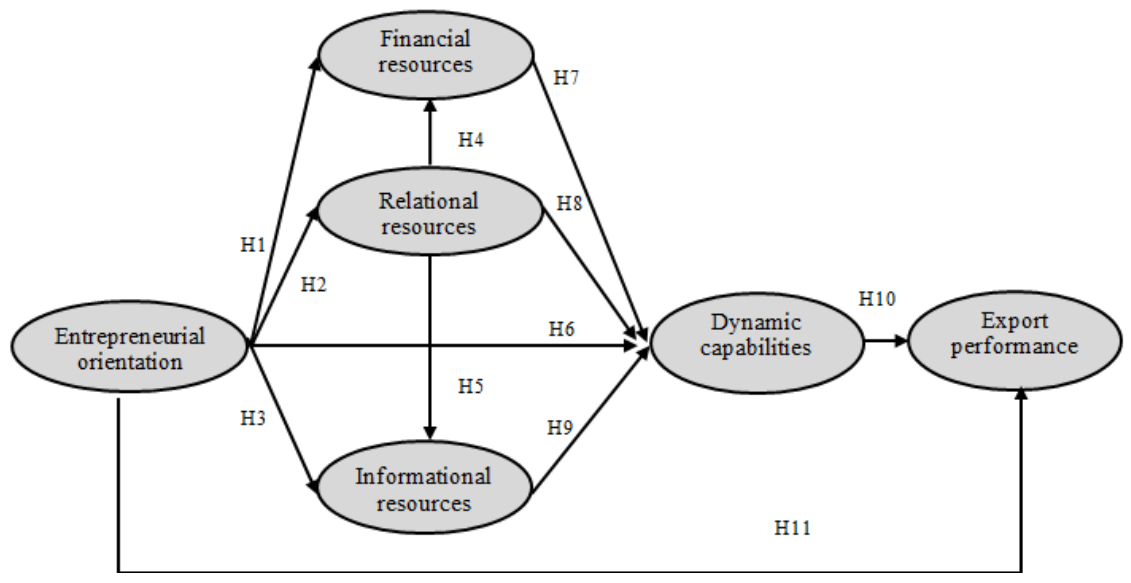

\section{Methodology}

\subsection{Research design and measures}

This study uses the questionnaire method, which is consistent with the majority of studies in the literature on export performance (Sousa et al., 2008). The questionnaire was pre-tested with academics and exporting firms to identify difficulties with the analysis instrument and provide suggestions for improvement. The final questionnaire consisted of two parts. The first part included information about the firm and its export activity. The second part consisted of questions related to entrepreneurial orientation, intangible resources (financial, informational and relational resources), dynamic capabilities, and export performance (see Table 1).

Table 1 Measurement scales used in the questionnaire

\begin{tabular}{|c|c|c|}
\hline Construct & Dimensions & References \\
\hline Entrepreneurial orientation & Innovation, proactiveness, risk taking & Covin and Slevin (1989) \\
\hline Organisational resources & $\begin{array}{l}\text { Informational resources, relational } \\
\text { resources, financial resources }\end{array}$ & Morgan et al. (2006) \\
\hline Dynamic capabilities & & Wu and Wang (2007) \\
\hline Export performance & & Okpara (2009) \\
\hline
\end{tabular}


The questionnaire was applied online owing essentially to the short response time regardless of respondents' location (Ilieva et al., 2002) the unit of analysis in this research was the export venture. The study was conducted with Portuguese exporters. The choice of a single country is consistent with the literature (Sousa et al., 2008). The use of Portuguese firms is also relevant given the country's economic situation and its strong dependence on exports (Sousa et al., 2006; Lisboa et al., 2011).

Given the high number of exporting companies listed in the Portuguese official statistics body (17,330 firms listed in National Institute of Statistics), we focused on exporting firms in the northern region (6,653 records). Several studies have also restricted the analysis to certain regions of one country (e.g. Sousa et al., 2008). The link to the online questionnaire was sent by e-mail to the 1,780 firms' senior managers and/or leaders of export activity in the database, which provided the addresses. Miesenböck (1988) regards these managers as the most likely to respond to questionnaires, given their direct involvement and responsibility in export decisions. Moreover, Souza et al. (2008) found that the data from most studies in this area came from export managers.

Of the 1,780 companies, the e-mails of approximately 600 were undeliverable. We recovered most of the addresses by searching online or telephoning the company, to resend the e-mails. Then, to increase the response rate, we randomly telephoned selected firms to solicit an answer. Through these contacts, either at the stage of identifying new e-mails (undeliverable) or at the latter stage (telephone contact to solicit response), we identified 270 companies that did not export (never exported, or if they sold to foreign markets, they did so sporadically), provided services (not included in this study), or were closed or in the process of insolvency. We excluded these companies, which left 1,510 companies. During data collection, which started in November 2011 and ended in February 2012, 293 questionnaires were received, 265 of which were usable, for a response rate of $19.4 \%$ and $18 \%$, respectively; this rate is quite satisfactory because, according to Menon et al. (1999), the average response rate of top management is between $15 \%$ and $20 \%$. The final sample includes only companies whose respondent confirmed to be responsible for the company's international activity. We conducted data analysis using SPSS statistical software (version 19) and LISREL (version 8.8).

\subsection{Non-response bias}

In this study, the majority of responses were collected in the follow-up stage. To assess differences between groups, we compared the means of the respondents in the first group (first quartile) with those of the second group (fourth quartile) for all variables included in the conceptual framework using the Mann-Whitney $U$ test, which is recommended when the distributions do not meet the criteria of normality (Nachar, 2008). The results show that though most of the late response averages were higher than those of the initial responses, the differences were not statistically significant $(\mathrm{p}>0.05)$, and consequently non-response bias is not a significant problem in this study. 


\section{Results}

The results are based on the responses provided by 265 exporting companies from various industries in the north of Portugal (44 companies are from the textile industry, 18 from the shoe industry, 15 from industrial equipments and products, 14 from house and furniture, 13 from the home apparel, and the remaining from various other industries).

\subsection{Structural equation model}

To test the causal relationships between different constructs, we used structural equation modelling because the theoretical model includes complex relationships among latent variables, and measures of different items are presented simultaneously as independent and dependent variables. With this type of analysis, it is necessary to choose the type of input matrix and the estimation technique. We used the covariance matrix because we intended to test a conceptual structure (Hair et al., 1998). Bentler et al. (2001) however report that the use of a matrix of correlations may show incorrect chi-square tests and standard errors estimates. The estimation technique we adopt in this study is the maximum likelihood method. This method is the most widely used (Anderson and Gerbing, 1988; Baumgartner and Homburg, 1996), yielding more reliable estimates when using covariance matrices (Byrne, 1998), and is also deemed robust against violations of the normality assumptions (Diamantopoulos and Siguaw, 2000). The analysis using the structural equation model comprises the assessment of the measurement model and the assessment of the structural model.

Table 2 Measurement model results

\begin{tabular}{lc}
\hline Construct and items & $\begin{array}{c}\text { Standardised } \\
\text { loading }\end{array}$ \\
\hline Financial resources $(C R=0.96, A V E=0.89)$ & 0.91 \\
Access to capital speed of acquiring & 0.95 \\
Ability to find additional financial resources when needed & 0.94 \\
Speed of acquiring and deploying financial resources & \\
Relational resources $(C R=0.90, A V E=0.74)$ & 0.82 \\
Strength of existing customer relationships in this export market & 0.85 \\
Duration of relationships with our current distributors in this market & 0.91 \\
Closeness of existing customer relationships & \\
Informational resources $(C R=0.92, A V E=0.80)$ & 0.91 \\
Export market information & 0.89 \\
Customer knowledge in this export market & 0.87 \\
Knowledge of competitors in this export market & \\
Dynamic capabilities $(C R=0.95, A V E=0.81)$ & 0.87 \\
Resource integration capability & 0.93 \\
Resource reconfiguration capability & 0.94 \\
Learning capability & 0.86 \\
Ability to respond to the rapidly changing environment & \\
\hline
\end{tabular}


Table 2 Measurement model results (continued)

\begin{tabular}{|c|c|}
\hline Construct and items & $\begin{array}{l}\text { Standardised } \\
\text { loading }\end{array}$ \\
\hline \multicolumn{2}{|l|}{ Entrepreneurial orientation } \\
\hline Innovation $(C R=0.87, A V E=0.71)$ & 0.78 \\
\hline $\begin{array}{l}\text { The past five years, the company has launched very new lines of products or } \\
\text { services. }\end{array}$ & 0.82 \\
\hline $\begin{array}{l}\text { The past five years, the company changes in product or services lines have } \\
\text { usually been quite dramatic. }\end{array}$ & 0.86 \\
\hline Proactiveness $(C R=0.82, A V E=0.64)$ & 0.82 \\
\hline $\begin{array}{l}\text { In dealing with its competitors, my firm typically initiates actions which } \\
\text { competitors the respond to. }\end{array}$ & 0.72 \\
\hline $\begin{array}{l}\text { In dealing with its competitors, my firm is very often the first business to } \\
\text { introduce new products/services, administrative techniques, operating } \\
\text { technologies, etc. }\end{array}$ & 0.80 \\
\hline \multicolumn{2}{|l|}{ Risk taking $(C R=0.87, A V E=0.71)$} \\
\hline $\begin{array}{l}\text { In general, the top managers of my firm have a strong proclivity for high-risk } \\
\text { projects (with chances of very high returns. }\end{array}$ & 0.80 \\
\hline $\begin{array}{l}\text { In general, the top managers of my firm have owing to the nature of the } \\
\text { environment. Bold, wide-ranging acts are necessary to achieve the firm's } \\
\text { objectives. }\end{array}$ & 0.93 \\
\hline $\begin{array}{l}\text { When confronted with decision-making situations involving uncertainty, my } \\
\text { firm typically adopts a bold, aggressive posture in order to maximise the } \\
\text { probability of exploiting potential opportunities. }\end{array}$ & 0.78 \\
\hline \multicolumn{2}{|l|}{ First- and second-order factors } \\
\hline - innovation - entrepreneurial orientation & 0.64 \\
\hline - proactiveness - entrepreneurial orientation & 0.76 \\
\hline - risk taking - entrepreneurial orientation & 0.57 \\
\hline \multicolumn{2}{|l|}{ Correlation factor } \\
\hline - innovation - proactiveness $\left(\mathrm{R}^{2}=0.41\right)$ & 0.64 \\
\hline - innovation - risk taking $\left(\mathrm{R}^{2}=0.18\right)$ & 0.43 \\
\hline - proactiveness - risk taking $\left(\mathrm{R}^{2}=0.20\right)$ & 0.45 \\
\hline \multicolumn{2}{|l|}{ Export performance $(C R=0.92, A V E=0.79)$} \\
\hline We have achieved a rapid growth in our export activities in the last three years. & 0.93 \\
\hline We have expanded our operations in the last three years. & 0.93 \\
\hline Overall the performance of our firm has been very satisfactory. & 0.81 \\
\hline
\end{tabular}

We evaluated the measurement model in terms of the constructs' unidimensionality, reliability, and validity (convergent and discriminant). Table 2 provides the evaluation results of the measurement model. In the first-order models, all items load statistically significantly on their factor, thus demonstrating the unidimensionality of the single factor, and all loadings of the observed variables have values greater than 0.70 , demonstrating the convergent validity of the constructs (Garver and Mentzer, 1999). All latent variables have good levels of composite reliability, with values greater than 0.60 , which proves the reliability of the scales (Bagozzi and Yi, 1988). The average variance 
extracted is greater than 0.50 , providing evidence of discriminant validity of the constructs (Fornell and Larcker, 1981). In the second-order models (entrepreneurial orientation), the statistical significance of associations between the first- and second-order factors is confirmed. That is, the coefficients exceed the minimum threshold of 0.40 , confirming the convergent validity of the construct (Nunnally and Bernstein, 1994), and the square of the correlation is less than the average variance extracted for each factor, evidencing discriminant validity of the construct (Fornell and Larcker, 1981).

To test the proposed hypotheses, we estimated the structural model. Analysis of the parameters confirms the fit of the model $\left(X^{2}(141)=227,30 ; p<0.05\right.$, CFI $=0.99$, GFI $=0.92$, NNFI $=0.99$, RMSEA $=0.048$ ). We present in Table 3 the hypothesis testing results and in Table 4 the means, standard deviations, and correlations.

Table 3 Hypothesis-testing results

\begin{tabular}{|c|c|c|c|c|c|}
\hline Parameters & $\begin{array}{l}\text { Standardis } \\
\text { ed loading }\end{array}$ & t-value & $R^{2}$ & Hypotheses & Results \\
\hline $\begin{array}{l}\text { Entrepreneurial orientation - } \\
\text { financial resources }\end{array}$ & 0.14 & 1.82 & 0.21 & $\mathrm{H} 1$ & Not supported \\
\hline $\begin{array}{l}\text { Relational resources - } \\
\text { financial resources }\end{array}$ & 0.41 & $6.27 *$ & & $\mathrm{H} 4$ & Supported H2 \\
\hline $\begin{array}{l}\text { Entrepreneurial orientation - } \\
\text { relational resources }\end{array}$ & 0.27 & $3.43 *$ & 0.07 & & Supported H3 \\
\hline $\begin{array}{l}\text { Entrepreneurial orientation - } \\
\text { informational resources }\end{array}$ & 0.23 & $3.27 * *$ & 0.35 & & Supported H5 \\
\hline $\begin{array}{l}\text { Relational resources - } \\
\text { informational resources }\end{array}$ & 0.49 & $7.52 *$ & & & Supported H6 \\
\hline $\begin{array}{l}\text { Entrepreneurial orientation - } \\
\text { dynamic capabilities }\end{array}$ & 0.20 & $3.18 * *$ & 0.53 & & Supported H7 \\
\hline $\begin{array}{l}\text { Financial resources - } \\
\text { dynamic capabilities }\end{array}$ & 0.14 & $2.68 * *$ & & & Supported H8 \\
\hline $\begin{array}{l}\text { Relational resources - } \\
\text { dynamic capabilities }\end{array}$ & 0.31 & $4.68 *$ & & & Supported H9 \\
\hline $\begin{array}{l}\text { Informational resources - } \\
\text { dynamic capabilities }\end{array}$ & 0.32 & $5.02 *$ & & & Supported \\
\hline $\begin{array}{l}\text { Dynamic capabilities - } \\
\text { export performance }\end{array}$ & 0.26 & $3.85 *$ & 0.37 & $\mathrm{H} 10$ & Supported \\
\hline $\begin{array}{l}\text { Entrepreneurial orientation - } \\
\text { export performance }\end{array}$ & 0.45 & $5.27^{*}$ & & H11 & Supported \\
\hline
\end{tabular}

Table 4 Means, standard deviations and correlations

\begin{tabular}{|c|c|c|c|c|c|c|c|c|}
\hline & $M$ & $S D$ & 1 & 2 & 3 & 4 & 5 & 6 \\
\hline 1 Export performance & 4.60 & 1.62 & 1.00 & & & & & \\
\hline 2 Dynamic capabilities & 4.74 & 1.15 & 0.45 & 1.00 & & & & \\
\hline 3 Informational resources & 5.04 & 1.17 & 0.31 & 0.60 & 1.00 & & & \\
\hline 4 Financial resources & 4.42 & 1.45 & 0.21 & 0.42 & 0.27 & 1.00 & & \\
\hline 5 Relational resources & 5.28 & 1.00 & 0.28 & 0.61 & 0.55 & 0.45 & 1.00 & \\
\hline 6 Entrepreneurial orientation & 4.03 & 1.47 & 0.56 & 0.43 & 0.36 & 0.24 & 0.27 & 1.00 \\
\hline
\end{tabular}


The results show that

1 entrepreneurial orientation enhances the attraction of informational and relational resources, but not financial resources

2 the presence of organisational resources (financial, informational and relational resources) is an important factor in the development of dynamic capabilities

3 dynamic capabilities affect export performance

4 entrepreneurial orientations affect directly and indirectly export performance.

In addition, we tested the mediating effect of organisational resources and dynamic capabilities. We tested the significance of the mediating effect using the Aroian test (Baron and Kenny, 1986). The results show that the entrepreneurial orientation does not directly impact financial resources but has an indirect effect through mass relational resources, of $0.11(0.27 \times 0.41)$. Entrepreneurial orientation has a significant indirect impact on dynamic capabilities through organisational resources (0.24). Finally, the indirect effect of entrepreneurial orientation on export performance is 0.11 , the total effect being $0.56(0.11+0.45)$.

\section{Discussion and conclusions}

The survival and expansion of companies and the consequent economic growth of many countries calls for a better understanding of the determinants that influence international performance (Sousa et al., 2008). Research in this field has focused mainly on how resources and capabilities help companies achieve sustainable competitive advantage and superior performance in foreign markets.

This study proposes and tests a model in which entrepreneurial orientation has a positive direct or indirect influence on organisational resources (financial, informational and relational resources) and enhances the development of dynamic capabilities, which mediate the effect of entrepreneurial orientation on export performance.

From the responses to an online questionnaire of top managers in 265 exporting firms, we validated all but one of the direct relationships of the model, (the exception being the relationship between entrepreneurial orientation and financial resources) and confirmed the mediating effect of organisational resources and dynamic capabilities on export performance. Specifically, we found that entrepreneurial orientation enhances the attraction of informational and relational resources, that relational resources boost the development of informational and financial resources, and that these four types of resources and capabilities (entrepreneurial orientation, financial resources, informational resources, and relational resources) influence the development of dynamic capabilities. These results are consistent with previous studies in this area (Morgan et al., 2004; Wu, 2006; Wu and Wang, 2007) and with Morgan et al.'s (2004) argument that resources and capabilities are inter-related. The impact of resources on dynamic capabilities confirms Wu's (2006) study as well as the proposition that resources are antecedents of the development of capabilities (e.g., Morgan et al., 2004). The influence of dynamic capabilities on export performance is consistent with the results of Wu's (2006) and Wu and Wang's (2007) study on technological companies and internal market performance. Finally, the findings on the impact of entrepreneurial orientation on performance are 
consistent with those of several studies (e.g. Covin and Slevin, 1989; Covin et al., 1990; Lumpkin and Dess, 1996; Miller, 1983).

Entrepreneurial orientation, organisational resources, and dynamic capabilities positively affect (directly and indirectly) export performance. For one side, these results support RBV and DCV generic tenets regarding the importance of the resource base of the company, for international performance. More than that, however, the developed model adds to the understanding of the role and nature of the relationships between entrepreneurial orientation, resources and capabilities and how they contribute to performance. Specifically, entrepreneurial orientation allows creating and coordinating organisational resources and developing capabilities, and these sustain long term performance export performance (Teece, 2007).

As with most studies, this research is not without limitations, which should be considered when interpreting and generalising the results. The first limitation is the potential bias caused by the sample size and measurement. Similar to previous studies, we used seven-point Likert scales to evaluate the constructs; as such, the majority of the answers are based on the respondents' subjective judgments. Although previous research has used subjective measures to assess the performance of exports, we acknowledge that some responses may not reflect the actual situation of the level of resources and capabilities available to the export venture. In addition, although e-mail is a commonly used tool, we cannot generalise the results to the total population.

Second, it also could be argued that evaluating the different variables in this study on the basis of the opinion of one respondent per firm may not accurately reflect the reality of companies. Especially in large companies, more than one person makes decisions, and they may have different opinions on the export activity (Leonidou and Katsikeas, 1996).

These limitations provide potential future directions for research. For example, this study does not account for the moderating effects of some variables (e.g. hostile external environment) or the effects of control variables such as firm size and demographic characteristics of the respondents, which could lead to greater insights.

A better understanding of how companies develop differentiated dynamic capabilities is paramount for managers, public policy makers, and researchers who want to contribute to firms' competitiveness and performance.

\section{References}

Alvarez, S.A. and Busenitz, L.W. (2001) 'The entrepreneurship of resource-based theory', Journal of Management, Vol. 27, No. 6, pp.755-775.

Amit, R. and Schoemaker, P.J.H. (1993) 'Strategic assets and organizational rent', Strategic Management Journal, Vol. 14, No. 1, pp.33-46.

Anand, V., Glick, W.H. and Manz, C.C. (2002) 'Thriving on the knowledge of outsiders: tapping organizational social capital', Academy of Management Executive, Vol. 16, No. 1, pp.87-101.

Anderson, J.C. and Gerbing, D.W. (1988) 'Structural equation modeling in practice: a review and recommended two-step approach', Psychology Bulletin, Vol. 103, No. 3, pp.411-423.

Arndt, J. (1979) 'Toward a concept of domesticated markets', Journal of Marketing, Vol. 43, No. 4, pp.69-75.

Bagozzi, R.P. and Yi, Y. (1988) 'On the evaluation of structural equation models', Journal of the Academy of Marketing Science, Vol. 16, No. 1, pp.74-94. 
Bakar, L.J.A. and Ahmad, H. (2010) 'Assessing the relationship between firm resources and product innovation performance: a resource-based view', Business Process Management, Vol. 16, No. 3, pp.420-435.

Barney, J.B. (1991) 'Firm resources and sustained competitive advantage', Journal of Management, Vol. 17, No. 1, pp.99-120.

Baron, R.M. and Kenny, D.A. (1986) 'The moderator-mediator variable distinction in social psychological research: conceptual, strategic, and statistical considerations', Journal of Personality and Social Psychology, Vol. 51, No. 6, pp.1173-1182.

Baumgartner, H. and Homburg, C. (1996) 'Applications of structural equation modeling in marketing and consumer research: a review', International Journal of Research in Marketing, Vol. 13, No. 2, pp.139-61.

Bentler, P., Bagozzi, R.P., Cudeck, R. and Iacobucci, D. (2001) 'Structural equations modeling SEM using correlations or covariance matrices', Journal of consumer Psychology, Vol. 10, No. $1 / 2$, pp.85-87.

Byrne, B. (1998) Structural Equation Modeling with LISREL, PRELIS, and SIMPLIS: Basic Concepts, Applications and Programming, Lawrence Erlbaum Associates, Mahwah, NJ.

Cavusgil, S.T. and Zou, S. (1994) 'Marketing strategy-performance relationship: an investigation of the empirical link in export market ventures', Journal of Marketing, Vol. 58, No. 1, pp.1-21.

Covin, J.G. and Slevin, D.P. (1989) 'Strategic management of small firms in hostile and benign environments', Strategic Management Journal, Vol. 15, No. 2, pp.159-166.

Covin, J.G., Slevin, D.P. and Covin, T.J. (1990) 'Content and performance of growth-seeking strategies: a comparison of small firms in high-and low technology industries', Journal of Business Venturing, Vol. 5, No. 6, pp.391-412.

Davis, D.F. and Mentzer, J.T. (2008) 'Relational resources in interorganizational exchange: the effects of trade equity and brand equity', Journal of Retailing, Vol. 84, No. 4, pp.435-448.

Dhanaraj, C. and Beamish, P.W. (2003) 'A resource-based approach to the study of export performance', Journal of Small Business Management, Vol. 41, No. 3, pp.242-261.

Diamantopoulos, A. and Siguaw, J.A. (2000) Introducing LISREL, Sage Publications, London.

Eisenhardt, K.M. and Martin, J.A. (2000) 'Dynamic capabilities: what are they?', Strategy Management Journal, Vol. 21, Nos. 10/11, pp.1105-1121.

Etemad, H. (2005) 'SMEs' internationalization strategies based on a typical subsidiary's evolutionary life cycle in three distinct stages', Management International Review, Vol. 45, No 3, pp.145-186.

Fornell, C. and Larcker, D. (1981) 'Evaluating structural equation models with unobserved variables and measurement error', Journal of Marketing Research, Vol. 18, No. 1, pp.39-50.

Garver, M.S. and Mentzer, J.T. (1999) 'Logistics research methods: Employing structural equation modeling to test for construct validity', Journal of Business Logistics, Vol. 20 No. 1, pp.33-57.

Grant, R.M. (1996) 'Toward a knowledge-based theory of the firm', Strategic Management Journal, Vol. 17, No. S2, pp.109-122.

Hair Jr., J.F., Anderson, R.E., Tatham, R.L. and Black, W.C. (1998) Multivariate Data Analysis, 5th ed., Prentice Hall, Englewood Cliffs, NJ.

Helfat, C.E. and Peteraf, M. (2003) 'The dynamic resource-based view: capability lifecycles', Strategic Management Journal, Vol. 24, No. 10, pp.997-1010.

Henderson, R. and Cockburn, I. (1994) 'Measuring competence? Exploring firm effects in pharmaceutical research', Strategic Management Journal, Vol. 15, Special Issue, pp.63-84.

Hung-Hsin, C. and Lee, P-Y. (2009) 'The driving drivers of dynamic competitive capabilities: a new perspective on competition', European Business Review, Vol. 21, No. 1, pp.78-91.

Ilieva, J., Baron, S. and Healey, N.M. (2002) 'Online surveys in marketing research: pros and cons’, International Journal of Market Research, Vol. 44, No. 3, pp.361-382. 
Ireland, R.D., Hitt, M.A., Camp, S.M. and Sexton, D.L. (2001) 'Integrating entrepreneurship and strategic management actions to create firm wealth', Academy of Management Executive, Vol. 15, No. 1, pp.49-63.

Johanson, J. and Vahlne, J-E. (1977) 'The internationalization process of the firm - a model of knowledge development and increasing foreign market commitments', Journal of International Business Studies, Vol. 8, No. 1, pp.23-32.

Katsikeas, C.S. and Morgan, R.E. (1994) 'Differences in perceptions of exporting problems based on firm size and export market experience', European Journal of Marketing, Vol. 28 No. 5, pp.17-35.

Katsikeas, C.S., Leonidou, C.L. and Morgan, N.A. (2000) 'Firm-level export performance assessment: review, evaluation, and development', Journal of the Academy of Marketing Science, Vol. 28, No. 4, pp.493-511.

Kropp, F., Lindsay, N.J. and Shoham, A. (2008) 'Entrepreneurial orientation and international entrepreneurial business venture startup', International Journal Entrepreneurial Behaviour and Research, Vol. 14, No. 2, pp.102-117.

Lages, L.F. and Montgomery, D.B. (2004) 'Export performance as an antecedent of export commitment and marketing strategy adaptation: evidence from small and medium-sized exporters', European Journal of Marketing, Vol. 38, Nos. 9/19, pp.1186-1214.

Lee, J-S. and Hsien, C-J. (2010) 'A research in relating entrepreneurship, marketing capability, innovative capability and sustained competitive advantage', Journal of Business and Economics Research, Vol. 8, No. 9, pp.109-120.

Leonidou, L.C. and Katsikeas, C.S. (1996) 'The export development process: an integrative review of empirical models', Journal of International Business Studies, Vol. 27, No. 3, pp.517-551.

Leonidou, L.C., Katsikeas, C.S., Palihawadana, D. and Spyropoulou, S. (2007) 'An analytical review of the factors stimulating smaller firms to export: implications for policy-makers', International Marketing Review, Vol. 24, No. 6, pp. 735-770.

Lisboa, A., Skarmeas, D. and Lages, C. (2011) 'Entrepreneurial orientation, explotative and explorative capabilities, and performance outcomes in export markets: a resource-based approach', Industrial Marketing Management, Vol. 40, pp.1274-1284.

Loane, S. and Bell, J. (2006) 'Rapid internationalisation among entrepreneurial firms in Australia, Canada, Ireland and New Zealand: an extension to the network approach', International Marketing Review, Vol. 23 No. 5, pp.467-485.

López, S.V. (2005) 'Competitive advantage and strategy formulation: the key role of dynamic capabilities', Management Decision, Vol. 43, No. 5, pp.661-669.

Lumpkin, G.T. and Dess, G.G. (1996) 'Clarifying the entrepreneurial orientation construct and linking it to performance', Academic of Management Review, Vol. 21, No. 1, pp.135-172.

Makadok, R. (2001) 'Toward a synthesis of the resource-based and dynamic-capability views of rent creation', Strategic Management Journal, Vol. 22, No. 5, pp.387-401.

Menon, A., Bharadwaj, S.G., Adidam, P.T. and Edison, S.W. (1999) 'Antecedents and consequences of marketing strategy making: a model and a test', Journal of Marketing, Vol. 63, No. 2, pp.18-40.

Miesenböck, K.J. (1988) 'Small businesses and exporting: a literature review', International Small Business Journal, Vol. 6, No. 2, pp.42-61.

Miller, D. (1983) 'The correlates of entrepreneurship in three types of firms', Management Science, Vol. 29 No. 7, pp.770-791.

Miller, D. and Shamsie, J. (1996) 'The resource-based view of the firm in two environments: the Hollywood film studios from 1936 to 1965', Academy of Management Journal, Vol. 39, No. 3, pp.519-543.

Morgan, N.A., Kaleka, A. and Katsikeas, C.S. (2004) 'Antecedents of export venture performance: a theoretical model and empirical assessment', Journal of Marketing, Vol. 68, No. 1, pp.90108 . 
Morgan, N.A., Vorhies, D.W. and Schlegelmilch, B.B. (2006) 'Resource-performance relationships in industrial export ventures: the role of resource inimitability and substitutability', Industrial Marketing Management, Vol. 35, No. 5, pp.621-633.

Mowery, D.C., Oxley, J.E. and Silverman, B.S. (1996) 'Strategic alliances and interfirm knowledge transfer', Strategic Management Journal, Vol. 17, Winter Special Issue, pp.77-91.

Nachar, N. (2008) 'The Mann-Whitney U: a test for assessing whether two independente samples come from the same distribution', Tutorials in Quantitative Methods for Psychology, Vol. 4 No. 1, pp.13-20.

Newbert, S.L. (2007) 'Empirical research on the resource-based view of the firm: an assessment and suggestion for future research', Strategic Management Journal, Vol. 28, No. 2, pp.121146.

Nonaka, I. (1991) 'The knowledge-creating company', Harvard Business Review, Vol. 69, pp.96104.

Nunnally, J. and Bernstein, I. (1994) Psychometric Theory, 3rd ed., McGraw-Hill, New York, NY.

Okpara, J.O. (2009) 'Entrepreneurial orientation and export performance: evidence from an emergency economy', International Review of Business Research Papers, Vol. 5 No. 6, pp.195-211.

Peteraf, M.A. (1993) 'The cornerstones of competitive advantage: a resource-based view', Strategic Management Journal, Vol. 14, No. 3, pp.179-191.

Piercy, N.F., Kaleka, A. and Katsikeas, C.S. (1998) 'Sources of competitive advantage in high performing exporting companies', Journal of World Business, Vol. 33 No. 4, pp.278-393.

Schlegelmilch, B.B. and Crook, J.N. (1988) 'Firm-level determinants of export intensity', Managerial and Decision Economics, Vol. 9, No 4, pp.291-300.

Schumpeter, J.A. (1934) The Theory of Economic Development, Harvard University Press, Cambridge, MA.

Sousa, C.M.P. and Bradley, F. (2006) 'Cultural distance and psychic distance: two peas in a pod?', Journal of International Marketing, Vol. 14, No. 1, pp.49-70.

Sousa, C.M.P., Martínez-López, F.J. and Coelho, F. (2008) 'The determinants of export performance: a review of the research in the literatures between 1998 and 2005', International Journal of Management Reviews, Vol. 10, No. 4, pp.343-374.

Teece, D.J. (2007) 'Explicating dynamic capabilities: the nature and microfoundations of (sustainable) enterprise performance', Strategic Management Journal, Vol. 298, No. 13, pp.1319-1350.

Teece, D.J., Pisano, G. and Shuen, A. (1997) 'Dynamic capabilities and strategic management', Strategic Management Journal, Vol. 18, No. 7, pp.509-533.

Tsai, W. and Ghoshal, S. (1998) 'Social capital and value creation: the role of intrafirm networks', Academy of Management Journal, Vol. 41, No. 4, pp.464-476.

Vila, N. and Kuster, I. (2007) 'The importance of innovation in international textile firms', European Journal of Marketing, Vol. 41, Nos. 1/2, pp.17-36.

Wernerfelt, B. (1984) 'A resource-based view of the firm', Strategic Management Journal, Vol. 5, No. 2, pp.171-180.

Wiklund, J. and Shepherd, D. (2005) 'Entrepreneurial orientation and small business performance: a configurational approach', Journal of Business Venturing, Vol. 20, No. 1, pp.71-91.

$\mathrm{Wu}, \mathrm{L}-\mathrm{Y}$. (2006) 'Resources, dynamic capabilities and performance in a dynamic environment: perceptions in Taiwanese IT enterprises', Information and Management, Vol. 43, No. 4, pp.447-454.

$\mathrm{Wu}, \mathrm{L}-\mathrm{Y}$. (2010) 'Applicability of the resource-based and dynamic-capability views under environment volatility', Journal of Business Research, Vol. 63 No. 1, pp.27-31.

$\mathrm{Wu}, \mathrm{L}-\mathrm{Y}$. and Wang, C-J. (2007) 'Transforming resources to improve performance of technology-based firms: a Taiwanese empirical study', Journal of Engineering and Technology Management, Vol. 24, No. 3, pp.251-261. 
Young, S., Dimitratos, P. and Dana, L. (2003) 'International entrepreneurship research: what scope international business theories?', Journal of International Entrepreneurship, Vol. 1, No. 1, pp.31-42.

Zahra, S.A. and Covin, J.G. (1995) 'Contextual influences on the corporate entrepreneurshipperformance relationship: a longitudinal analysis', Journal of Business Venturing, Vol. 10, No. 1, pp.43-58.

Zou, S., Taylor, C.R. and Osland, G.E. (1998) 'The EXPERF scale: a cross-national generalized export performance measure', Journal of International Marketing, Vol. 6, No. 3, pp.37-58. 